\title{
DAILY AND MONTHLY ACTIVITY OF BROWN BEARS (URSUS ARCTOS) NEAR A PROPOSED INDUSTRIAL PROJECT IN COASTAL BRITISH COLUMBIA
}

\author{
Matthew L. Richardson 1,2
}

\begin{abstract}
The Kitimat Liquefied Natural Gas (KLNG) Plant is proposed for construction adjacent to Bish Creek (Kitimat, British Columbia, Canada). Bish Creek is a corridor for brown bears (Ursus arctos), and 8 camera traps were deployed along the creek for 1442 trapping days in 2014 to determine baseline activity of brown bears. Brown bear activity varied across weeks, peaking particularly in July and September. Within a 24 -h day, bears were commonly photographed during hours 5, 6, and 21 and uncommonly photographed during the 3 hours preceding noon and a 4-h period in the afternoon. However, the time of day that bears were photographed varied across seasons; bears were more commonly photographed during the day in July and at night in September. Understanding this change in activity across seasons will inform management of bear resources and human activities on-site to avoid human-bear interactions.
\end{abstract}

Resumen.-Se propone la construcción adyacente a Bish Creek (Kitimat, Columbia Británica, Canadá) de la planta Kitimat de Gas Natural Licuado (KLNG, por sus siglas en inglés). Bish Creek es un corredor para los osos pardos (Ursus arctos) en donde fueron puestas ocho cámaras trampa durante 1442 días en 2014 a lo largo del arroyo para determinar la actividad basal de los osos pardos. La actividad de los osos pardos varió a lo largo de las semanas, con un pico particular en julio y septiembre. Durante 24 horas de un día, los osos fueron normalmente fotografiados durante las horas 5,6 y 21 y raramente fotografiados dentro de las tres horas siguientes al mediodía y durante un período de cuatro horas por la tarde. Sin embargo, el momento del día en el que los osos fueron fotografiados variaron a lo largo de las estaciones: los osos fueron más comúnmente fotografiados durante el día en julio y por la noche en septiembre. La comprensión de este cambio en la actividad a lo largo de las estaciones ayudará a informar acerca del manejo de los recursos de los osos y de las actividades humanas en el lugar para evitar la interacción entre humanos y osos.

Kitimat, British Columbia, Canada, supports a large population of bears and has seen an increase in human activity in recent years due to industrial development. The Kitimat Liquefied Natural Gas (KLNG) Plant is proposed for construction in Bish Cove, which is where Bish Creek empties into the Kitimat arm of the Douglas Channel. Bish Creek is used for spawning by Pacific salmon species and is therefore a corridor for terrestrial wildlife that consume the salmon, such as brown bears (Ursus arctos L.) and black bears (Ursus americanus Pallas). However, the activity cycles of brown bears near the KLNG site are largely unknown.

Brown bears in Europe are largely nocturnal, and there is a distinct break in activity during the middle of the day (Kaczensky et al. 2006). Brown bears in North America are more likely to exhibit diurnal activity (Gende et al. 2001, Klinka and Reimchen 2002, McLellan and McLellan 2015), but predation on salmon may sometimes be more likely or more effective at twilight or night (Gard 1971, Olson et al. 1998, Klinka and Reimchen 2002). Brown bear activity also may be influenced by the intensity of human activities (reviewed in Fortin et al. 2016). Bears may be largely diurnal when humans are absent or inactive, but crepuscular or nocturnal in areas frequented by humans (Olson et al. 1998, Klinka and Reimchen 2002, Ordiz et al. 2013). However, bears can become habituated to humans and shift back to diurnal activity (Smith et al. 2005, Wheat and Wilmers 2016). This behavioral plasticity means that it can be difficult to predict when brown bears will be active.

Significant early works began at the proposed KLNG site in 2011 and involved a large workforce performing a multitude of front-end engineering and design activities, such as engineering assessments, vegetation removal (approximately 47.2 ha is proposed for clearance at Bish Cove), upgrade of an existing forest service road, construction of a new 2-lane bridge over Bish Creek, topographic leveling,

\footnotetext{
${ }^{1}$ Smithsonian Conservation Biology Institute, Center for Conservation and Sustainability, Washington, DC 20560.

${ }^{2}$ Present address: College of Agriculture, Urban Sustainability and Environmental Sciences, University of the District of Columbia, Washington, DC 20008. E-mail: matthew.richardson@udc.edu
} 


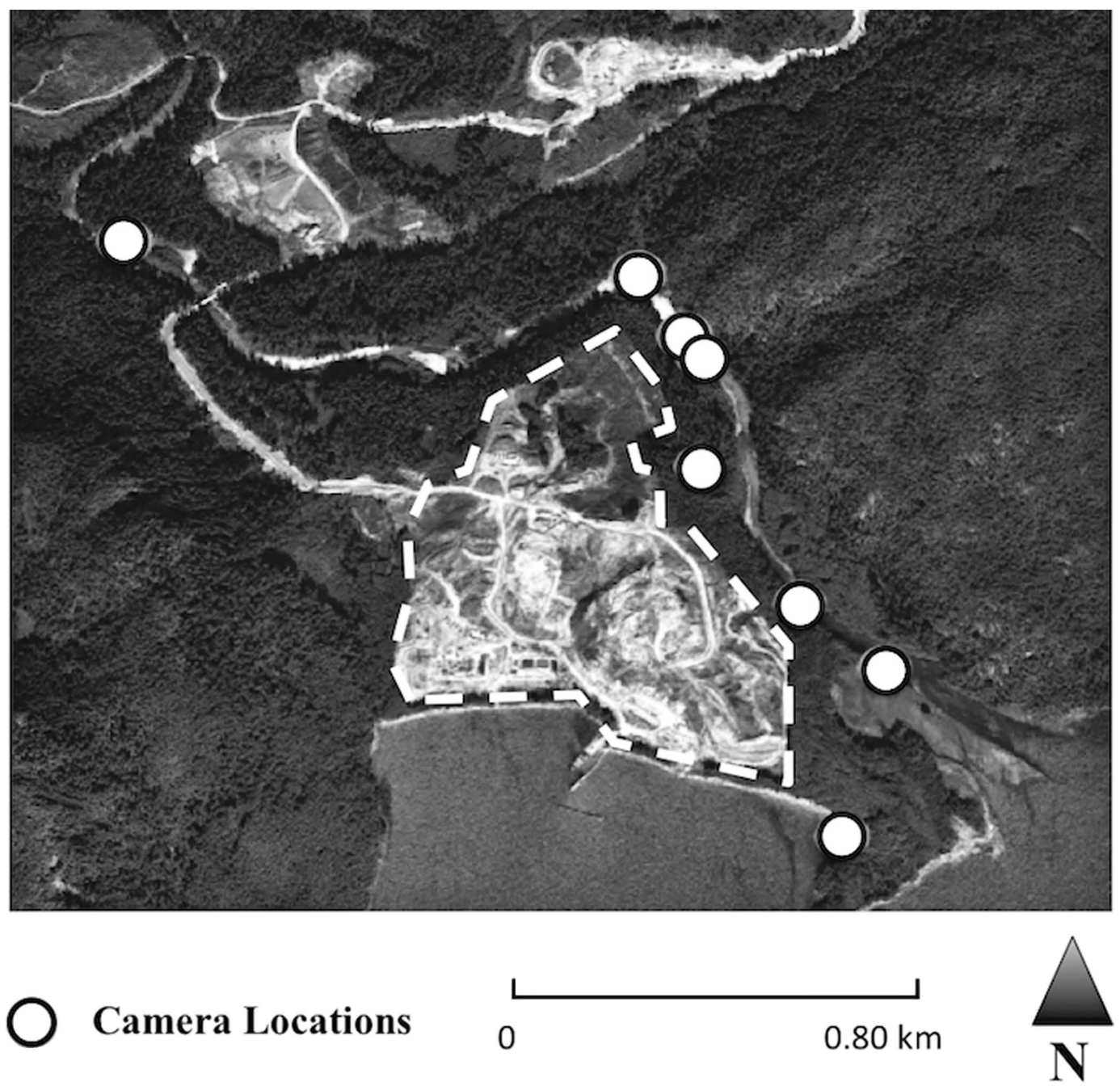

Fig. 1. Locations of 8 camera traps (filled circles) to sample brown bears near the proposed Kitimat Liquefied Natural Gas Plant (enclosed in dashed lines) in Bish Cove, where Bish Creek empties into the Kitimat arm of the Douglas Channel in British Columbia. Map data: Google, Digital Globe.

office establishment, creation of storage areas for equipment and natural materials, and excavation of borrow pits, as well as a variety of environmental monitoring and mitigation activities. These activities pose several potential threats to wildlife, including direct mortality, spread of disease and invasive species, direct encounters with humans, loss or alteration of habitats, and a decrease of habitat quality because of pollution, noise, and light disturbances that alter animal behavior. Camera traps were deployed along Bish Creek in 2014 to determine when brown bears are active and whether activity is associated with abiotic variables such as sunlight, lunar patterns, temperature, and precipitation. Ultimately, this effort will provide insight into the activity of brown bears in this region.

Eight Reconyx PC800 Hyperfire ${ }^{\mathrm{TM}}$ Professional (Reconyx Inc., Holmen, WI, USA) camera traps with infrared flash were installed along an approximately $3.1-\mathrm{km}$ length of Bish Creek in 2014 (Fig. 1). Locations for cameras were selected in consultation with KLNG personnel who knew of areas frequented by large mammals. Locations included 7 in open habitat along the creek and 2 in closed habitat in the woods. In both habitat types, cameras 
were placed along known wildlife trails to maximize detection of bears without use of bait. The earliest cameras were operational on 13 April, whereas the final one was operational by 31 May. Most cameras were left in place until 11-24 November, except for one which had to be removed in August. In total, 1441 trapping days were achieved during 2014. This coastal area of British Columbia is warmer than inland areas, so some bears were active outside of the trapping period. However, brown bear activity did not increase until the beginning of May and decreased by October (see Results), so the cameras should have captured most of the activity in the area. When triggered by an animal, cameras were programmed to take 5 consecutive photographs, with no time delay between photographs.

I organized camera trap photos by events. An event is a sequence of photos corresponding to a single individual or group of animals triggering the camera within $10 \mathrm{~min}$. I used 10 min as the basis to classify an event to limit counting an individual or group more than once in a short period of time in the analysis. For each event, I recorded the camera number, ordinal week and month, time (based on the first picture of the event), ambient temperature, moon phase, total precipitation that occurred on the trapping date, and total number of individual brown bears. Time and ambient temperature were recorded by the cameras and provided in the metadata for each image. The internal clock of each camera was standardized to the time at the study area. I standardized the time of the events to the average day of the observation period (following the methods of Kaczensky et al. 2006) in order to compare events that occurred during the same light regime. I also used the time of the event and sunrise/sunset data to determine whether events occurred during day, civil twilight, or night. The phases of the moon were divided into quarterly periods: (1) new moon through the last night before the first quarter; (2) first quarter through the last night before full moon; (3) full moon through the last night before the third quarter; and (4) third quarter through the last night before the new moon. The moon phases were provided in the metadata by the cameras, but I also used a moon phase calendar (www.moonconnection.com) to help divide the quarterly periods. Precipitation data from the local Kitimat weather station were accessed from Environment Canada (https://weather.gc.ca).

Differences in events per hour across weeks, months, standardized time of day, day/twilight/night, temperatures, precipitation, and moon phases, including interactions, were analyzed with the $F$-approximation of the Friedman test and the associated rank-sum multiple comparison test because the data could not be normalized with data transformations (PROC GLMMIX; SAS Institute 2008). Weeks 18-46 (27 April-15 November) were used in the final analysis to ensure that a minimum of 4 camera traps were simultaneously operational for all 7 days within a week.

The cameras captured 159 events of brown bears across the 29 weeks, and 14 of these events showed a female with cubs. There was a mean of 0.10 (SE 0.03) events per trapping day in open habitat and 0.10 (SE 0.07) events per trapping day in the closed (wooded) habitat. A variety of other animal species were captured by the camera traps, and 2 species, black bears and humans, have the potential for interspecific conflicts with brown bears. Black bears were photographed at a low rate: 0.02 (SE 0.02) events per trapping day in open habitat and 0.01 (SE 0.005) events per trapping day in closed (wooded) habitat. Humans also were photographed at a low rate in the open habitat (0.04 events/day, SE 0.03), but at rates equivalent to brown bears in closed habitat (0.10 events/day, SE 0.09).

Events of brown bears did not vary across temperatures $\left(F_{61,544}=0.79, P=0.88\right)$, precipitation amount $\left(F_{61,547}=0.78, P=0.89\right)$, or moon phases $\left(F_{3,602}=1.2, P=0.31\right)$. However, events varied across weeks $\left(F_{28,577}\right.$ $=2.1, P<0.001)$ and standardized time of day $\left(F_{23,120}=2.5, P<0.001\right)$, and were influenced by an interaction between months and day/twilight/night $\left(F_{14,582}=2.35, P=0.004\right)$. Bears were photographed most regularly in weeks 28 (approximately the first week of July), 30-31 (approximately the third and fourth weeks of July), and 37-39 (most of September) (Fig. 2). The extreme variability in early season activity was likely due to stochasticity. Bears were not photographed near the KLNG site during weeks 33-34 (beginning to mid-August) and weeks 44-45 (end of October into November) (Fig. 2). Bears were most frequently photographed during hours 5, 6, and 21 and least frequently photographed during later 


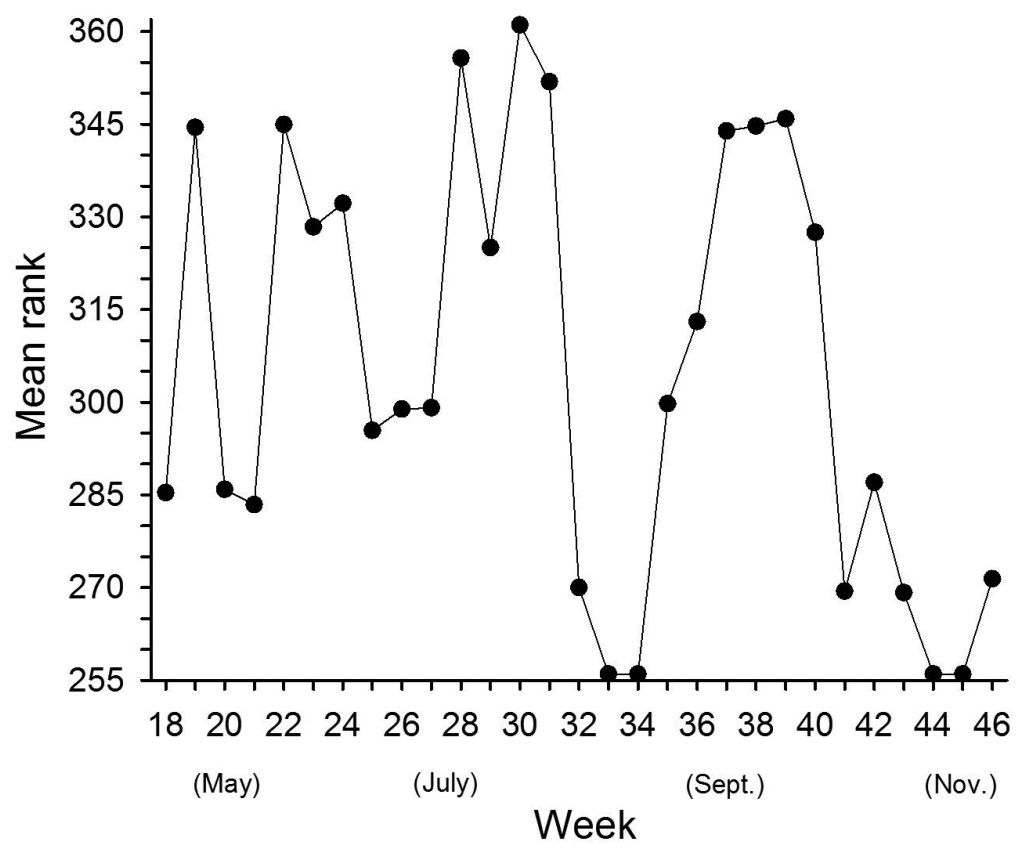

Fig. 2. Mean rank of brown bear events, as determined from 8 camera traps deployed near Kitimat, British Columbia, across 28 weeks in 2014. Weeks are listed as ordinal numbers and several months are provided as benchmarks.

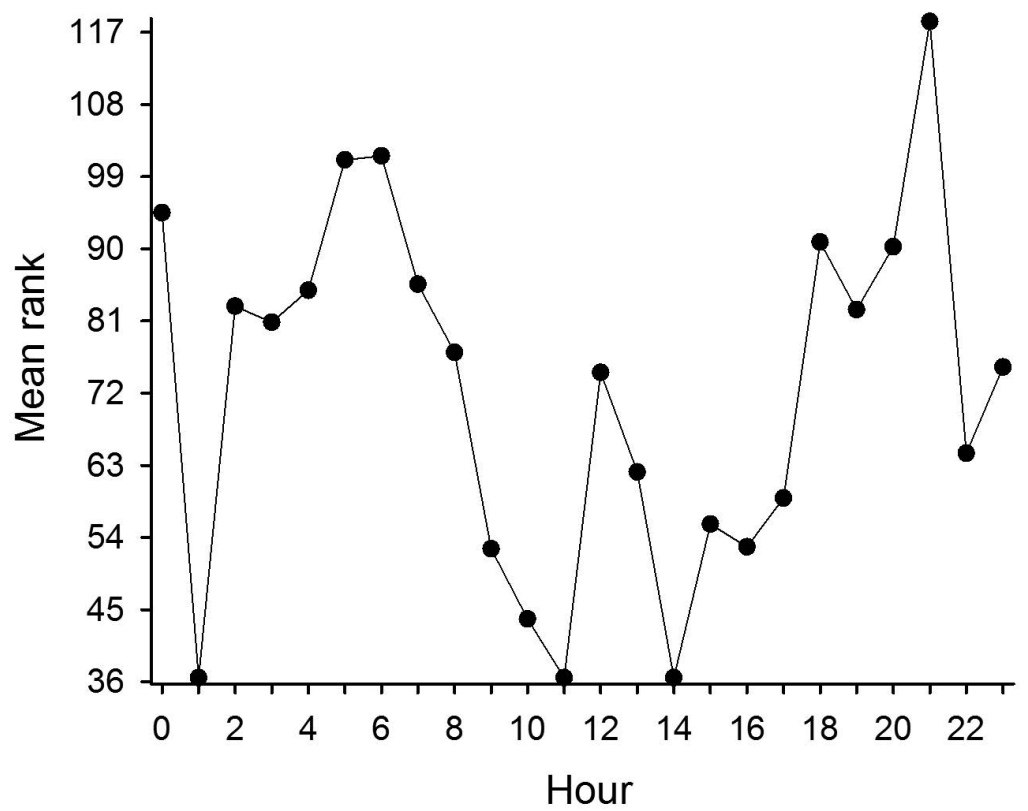

Fig. 3. Mean rank of brown bear events within a 24-h day. Means were calculated from 8 camera traps that were active from 27 April through 15 November 2014 near Kitimat, British Columbia. The time of each event was standardized to the average day of the observation period in order to compare events that occurred during the same light regime. 


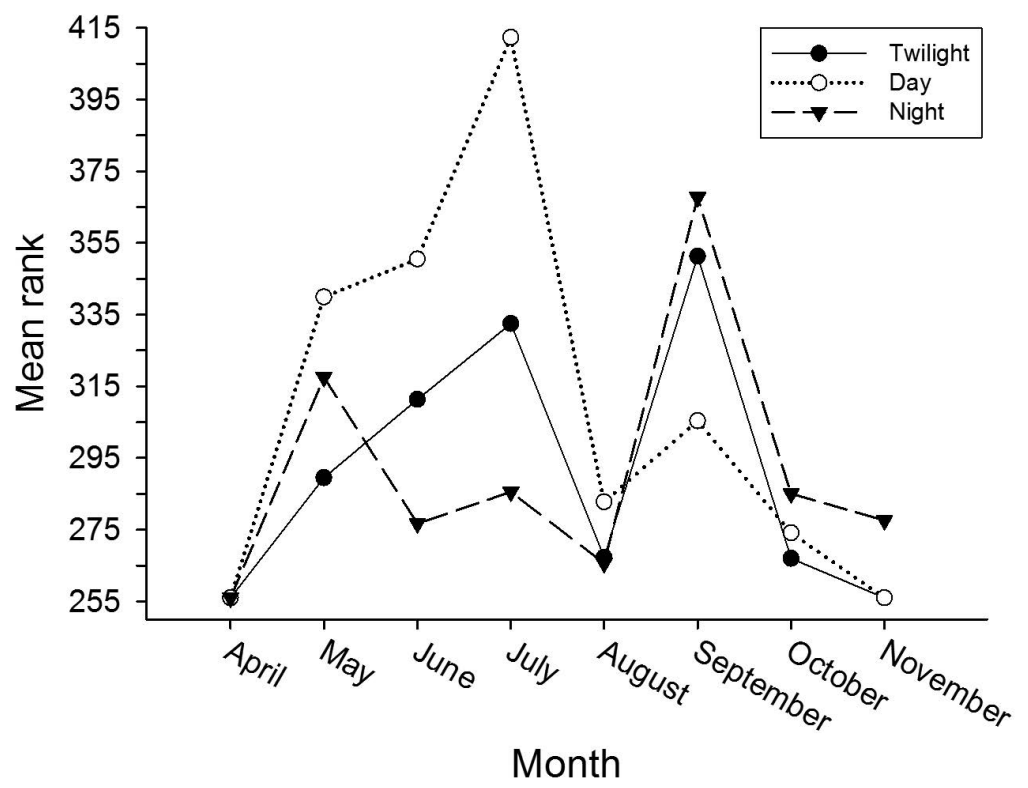

Fig. 4. Mean rank of brown bear events, as determined from 8 camera traps deployed near Kitimat, British Columbia, for 8 months in 2014. Events were influenced by the interaction between months and twilight/day/night.

morning and afternoon hours across all months (Fig. 3). However, the time of day that bears were photographed was not constant across seasons. Bears were more commonly photographed during the day in July and at night in September (Fig. 4).

The peaks in activity in July and September may coincide with the arrival and then death, respectively, of pink salmon (Oncorhynchus gorbuscha [Walbaum]) and chum salmon (Oncorhynchus keta [Walbaum]) in Bish Creek. Within a $24-\mathrm{h}$ period, bears were generally most active during early night and early morning hours. They were fairly active at other times, too, but there were 2 extended breaks in activity shortly before and after noon. Bear events were more numerous during the day in July and at night in September, and I can only speculate as to the reasons for this change. Brown bears are capable of shifting their temporal niche in response to the type and abundance of food resources (Fortin et al. 2013). Bears may catch fish by sight in July or may be still primarily consuming roots and berries, which are frequently exploited during the day (Munro et al. 2006, Fortin et al. 2013). By September the fish are dying and bears may rely on scent more than sight to find dead fish. Also, bears should have greatly increased their fat reserves by September and perhaps there are physiological advantages to nocturnal activity, such as avoidance of overheating or an overall reduction in energy expenditure. A hierarchical change also may occur: subadult bears and females with cubs may be more prevalent in July but could then be displaced by adult males in September. The former are known to be more active during the day, whereas the latter are more active at night (Klinka and Reimchen 2002, Kaczensky et al. 2006, Schwartz et al. 2010). The photographs from the camera traps seem to support the scenario that adult males replace subadults and females with cubs because only one event of a female with cubs occurred after 22 July 2014. However, I could not quantify the age of most bears due to the difficulty in determining size in many photographs, especially at night, and due to the overlap in body size of subadults and adults. I also cannot rule out the influence of human activities, which differentially influence brown bears based on their age and gender (McLellan and Shackleton 1988, MacHutchon et al. 1998, Nevin and Gilbert 2005). I am unaware of any changes at the KLNG site that would have caused a shift in bear activity over such a short time frame. However, fall is hunting season and even though bears were not hunted in proximity to the KLNG site, they may be responding 
to influences occurring somewhere else within their home ranges.

There are multiple liquified natural gas pipelines proposed for coastal British Columbia, as well as an oil pipeline and a variety of other industrial projects. Humans will be increasingly accessing bear habitat in British Columbia. Brown bears can become habituated to human presence and less aggressive (Jope 1985, Smith et al. 2005). However, habituated bears that associate food availability with people are more likely to seek food from people, damage property, and be killed (Herrero 2002). Therefore, cultural practices should be employed in areas where bears and humans overlap, such as properly disposing garbage daily that has the potential to attract wildlife and not directly feeding bears. Another way to reduce the likelihood of human-bear encounters is to become familiar with resources used by bears and how these resources may differentially influence activity patterns daily and seasonally (Fortin et al. 2013). Most attacks on humans by bears in North America are the result of sudden encounters during periods of high bear activity (Schwartz et al. 2010) when brown bears are reacting defensively to protect food or young (Herrero 2002). Whereas it is unrealistic to completely predict when and where bears will be active, especially as human activities at the KLNG site change over time, the data I collected can serve as a baseline to understand activity at the site and allow for the avoidance of human activities during peak bear activity.

I thank Jonquil Crosby, Mike Stekelenburg, and $\mathrm{Al}$ Hummel for field assistance, Danny Aiuto for database management, Sulema Castro for logistical support, Rob Heibein, Sheryl Maruca, and Maria Hartley for constructive discussions and site access, Ashley Myers for help creating Figure 1, and Alfonso Alonso and Francisco Dallmeier for help administering the research program. Funding was provided by the Kitimat LNG Operating General Partnership through an independent research agreement with the Smithsonian Institution.

\section{Literature Cited}

Fortin, J.K., K.D. Rode, G.V. Hilderbrand, J. Wilder, S. Farley, C. Jorgensen, and B.G. MarCot. 2016. Impacts of human recreation on brown bears (Ursus arctos): a review and new management tool. PLOS ONE 11: e0141983.

Fortin, J.K., J.V. Ware, H.T. Jansen, C.C. Schwartz, AND C.T. RobBins. 2013. Temporal niche switching by grizzly bears but not American black bears in Yellowstone National Park. Journal of Mammalogy 94:833-844.

GARD, G. 1971. Brown bear predation on sockeye salmon at Karluk Lake, Alaska. Journal of Wildlife Management 35:193-204.

Gende, S.M., T.P. Quinn, AND M.F. WiLlson. 2001. Consumption choice by bears feeding on salmon. Oecologia 127:372-382.

Herrero, S. 2002. Bear attacks, their causes and avoidance. Lyons Press, Guilford, CT

JOPE, K.L. 1985. Implications of grizzly bear habituation to hikers. Wildlife Society Bulletin 13:32-37.

Kaczensky, P., D. Huber, F. Knauer, H. Roth, A. WaGNER, AND J. KUSAK. 2006. Activity patterns of brown bears (Ursus arctos) in Slovenia and Croatia. Journal of Zoology 269:474-485.

KLINKA, D.R., AND T.E. ReImChen. 2002. Nocturnal and diurnal foraging behaviour of brown bears (Ursus arctos) on a salmon stream in coastal British Columbia. Canadian Journal of Zoology 80:1317-1322.

MacHutchon, A.G., S. Himmer, H. Davis, and M. GalLAGHER. 1998. Temporal and spatial activity patterns among coastal bear populations. Ursus 10:539-546.

McLellan, B.N., and D.M. Shackleton. 1988. Grizzly bears and resource-extraction industries: effects of roads on behaviour, habitat use and demography. Journal of Applied Ecology 25:451-460.

MCLELlan, M.L., AND B.N. MCLELLAN. 2015. Effect of season and high ambient temperature on activity levels and patterns of grizzly bears (Ursus arctos). PLOS ONE 10: e0117734.

Munro, R.H.M., S.E. Nielson, M.H. Price, G.B. StenHOUSE, AND M.S. Boyce. 2006. Seasonal and diel patterns of grizzly bear diet and activity in westcentral Alberta. Journal of Mammalogy 87:1112-1121.

Nevin, O.T., AND B.K. GILBERT 2005. Perceived risk, displacement and refuging in brown bears: positive impacts of ecotourism? Biological Conservation 121: 611-622.

Olson, T.L., R.C. SQuibB, AND B.K. GILBERT. 1998. Brown bear diurnal activity and human use: a comparison of two salmon streams. Ursus 10:547-555.

Ordiz, A., O.G. Støen, S. SÆbø, V. SahléN, B.E. PederSEn, J. Kindberg, AND J.E. Swenson 2013. Lasting behavioural responses of brown bears to experimental encounters with humans. Journal of Applied Ecology 50:306-314.

SAS INSTITUTE. 2008. SAS/STAT user's guide for personal computers. Release 9.2. SAS Institute, Cary, NC.

Schwartz, C.C., S.L. Cain, S. Podruzny, S. Cherry, and L. Frattaroli. 2010. Contrasting activity patterns of sympatric and allopatric black and grizzly bears. Journal of Wildlife Management 74:1628-1638.

Smith, T.S., S. Herrero, and T. DeBruyn. 2005. Alaskan brown bears, humans, and habituation. Ursus 16:1-10.

Wheat, R.E., and C.C. Wilmers. 2016. Habituation reverses fear-based ecological effects in brown bears (Ursus arctos). Ecosphere 7: $\mathrm{e} 01408$.

Received 22 June 2016

Accepted 9 January 2017

Published online 29 March 2017 